\title{
Chapter 9 \\ Wild Boars in Fukushima After the \\ Nuclear Power Plant Accident: \\ Distribution of Radiocesium
}

\author{
Keitaro Tanoi
}

\begin{abstract}
In the present chapter, I present the distribution of radiocesium in wild boars as well as the official monitoring data of wild boars from Fukushima. After the nuclear accident in 2011, the radiocesium contamination levels in wild boars from most places in Fukushima Prefecture exceeded $100 \mathrm{~Bq} / \mathrm{kg}$. The most contaminated wild boars were observed in Soso district where the radiocesium concentration in the soil was the highest in the entire Fukushima Prefecture. To understand radiocesium contamination in wild boars in more detail, we measured radiocesium concentrations in different organs and tissues of wild boars inhabiting Iitate Village in Soso district in 2012 and 2013. After capturing the wild boars, we collected 24 organs and tissues and put them into vials. Using an $\mathrm{NaI}(\mathrm{Tl})$ scintillation counter, we determined the concentrations of radiocesium $\left({ }^{134} \mathrm{Cs}\right.$ and $\left.{ }^{137} \mathrm{Cs}\right)$ and found that the levels were highest in the muscles (approximately $15,000 \mathrm{~Bq} / \mathrm{kg}$ ) and lowest in the ovaries (approximately $600 \mathrm{~Bq} / \mathrm{kg}$ ) in 2012, indicating a large variation between the organs and tissues. The trends were similar in 2012 and 2013. Observations of the contamination levels in wild boars could reveal the radiocesium availability in the forest and village ecosystem.
\end{abstract}

Keywords Fukushima Daiichi nuclear power plant accident - Wild boar • Radiocesium • Fission products • Food security • Wild animals • Wild life • Forest $\bullet$ Radioactive contamination

\subsection{Introduction}

Significant quantities of radiocesium were released during the accident at the Fukushima Dai-ichi Nuclear Power Plant (FDNPP) of the Tokyo Electric Power Company in March 2011 (Yasunari et al. 2011; Zheng et al. 2014). From soil

K. Tanoi $(\bowtie)$

Graduate School of Agricultural and Life Sciences, The University of Tokyo, 1-1-1 Yayoi,

Bunkyo-ku, Tokyo 113-8657, Japan

e-mail: uktanoi@mail.ecc.u-tokyo.ac.jp

(C) The Author(s) 2016

T.M. Nakanishi, K. Tanoi (eds.), Agricultural Implications of the Fukushima

Nuclear Accident, DOI 10.1007/978-4-431-55828-6_9 
measurements, it was shown that radiocesium was highly deposited in the northwestern region of the power plant (Saito et al. 2015). Fortunately, very small quantities of radiostrontium (Steinhauser et al. 2013) and plutonium (Zheng et al. 2012; Schneider et al. 2013) were deposited in the soil in most areas of Fukushima. Several months after the accident, the dominant radionuclides in the soil were ${ }^{134} \mathrm{Cs}$ and ${ }^{137} \mathrm{Cs}$. There have been many kinds of inspections of agricultural products and foods in Fukushima Prefecture, and the contamination levels in the wild animals of the forests, particularly wild boars, were found to be very high, presumably because wild boars have a habit of eating soil attached to their food, similar to an earthworm. Firstly, I summarized the inspection data of wild boars from Fukushima prefecture in the next section.

Data for radiocesium distribution in animals were limited. Green et al. (1961) reported the distribution of radiocesium and potassium in pigs and calves. Fukuda et al. (2013) reported radiocesium distribution in cattle. These reports showed that radiocesium levels were the highest in muscles and that there were large variations between the organs. Here, I present the radiocesium distribution within wild boars captured in Iitate Village where the habitants remain evacuated because of the high radiation levels caused by radiocesium deposition (Fig. 9.1).

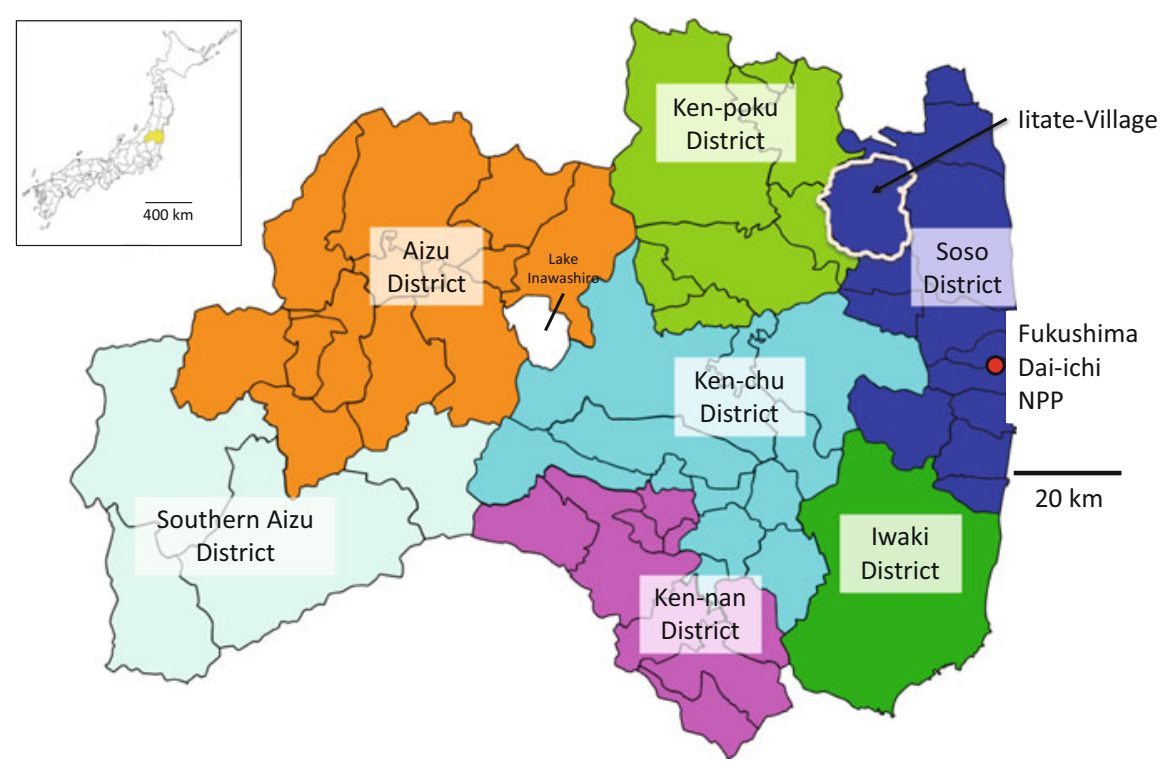

Fig. 9.1 Map of Iitate Village. Iitate Village is located in Soso district. The total area is 23,013 ha. Approximately $75 \%$ of the area is mountain or forest 


\subsection{Inspection Data from Fukushima}

The inspection data is accessible from the website "Fukushima Shinhatsubai" (http://www.new-fukushima.jp/monitoring/en/). I have summarized the data and separated it according to each district (Fig. 9.2). The radiocesium levels were high in Soso district, and the highest concentration of ${ }^{137} \mathrm{Cs}$ exceeded $50,000 \mathrm{~Bq} / \mathrm{kg}$ in 2013. Because the radiocesium levels remained high during these 4 years, we cannot speculate about when the meat of wild boars from this area can be used as food. From April 2012, the standard in Japan for the allowable radiocesium concentration in meat has been $100 \mathrm{~Bq} / \mathrm{kg}$ (Hamada et al. 2012). The current radiocesium levels in wild boar meat are now significantly higher than the standard level.

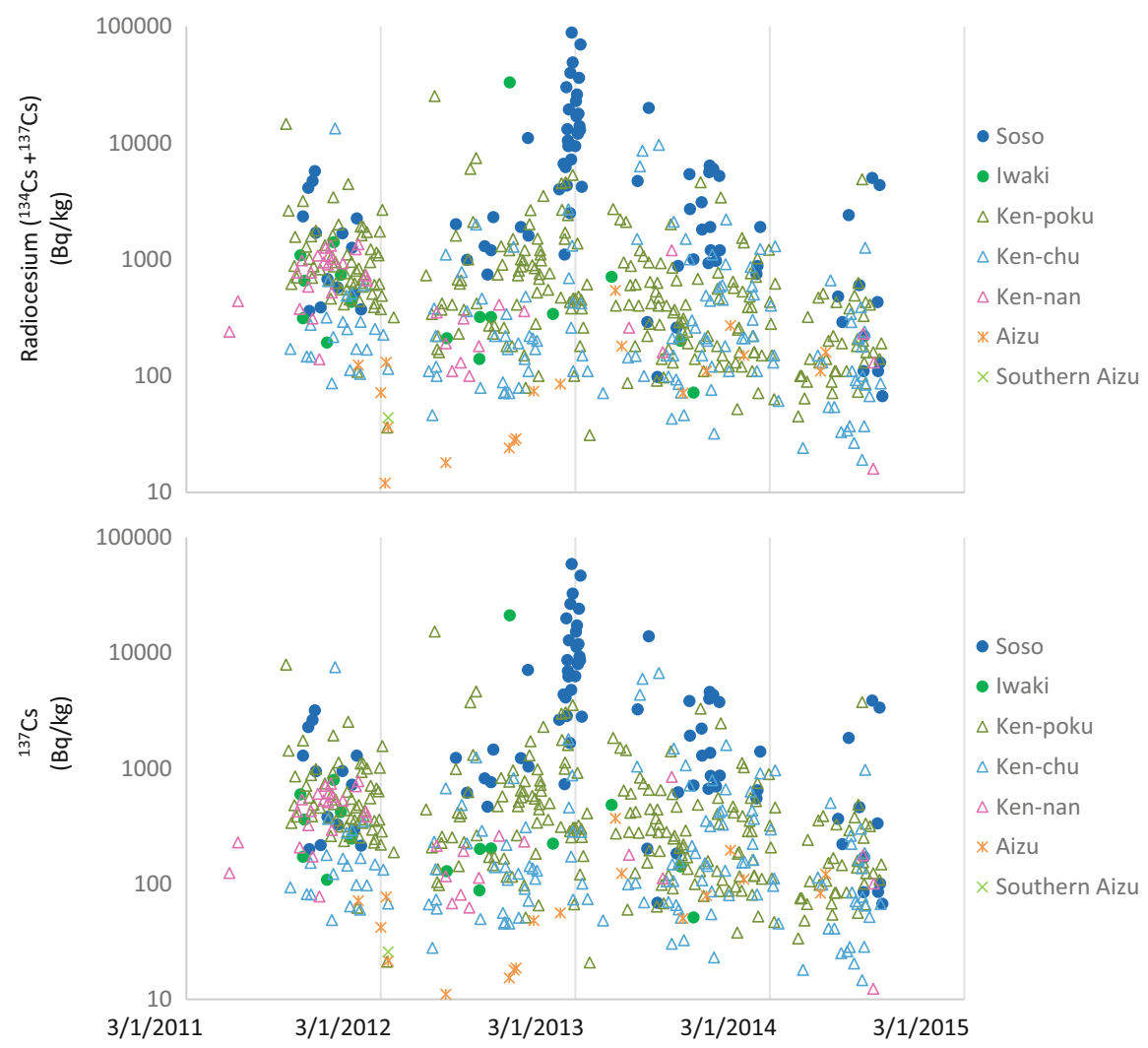

Fig. 9.2 Radiocesium concentrations in wild boars collected in Fukushima after the nuclear accident. Upper: Total radiocesium concentrations $\left({ }^{134} \mathrm{Cs}+{ }^{137} \mathrm{Cs}\right)$ in wild boars, which is the measure used to monitor food in Japan. Lower: ${ }^{137} \mathrm{Cs}$ concentrations in wild boars 


\subsection{Distribution of Radiocesium in Wild Boars in 2012 and 2013}

Because Iitate Village is now in the evacuation zone, damage to agricultural fields by wild animals such as monkeys and wild boars has been increasing. Before the nuclear power plant accident, hunting was performed to control the number of wild animals, and some of the hunted animals such as wild boars and deer were sold for meat. However, the radiocesium contamination in wild animals now prevents people from hunting them. The wild animal problem has become more serious with time.

In 2012, members of the NPO "Resurrection of Fukushima" and researchers from the University of Tokyo started to investigate the radiocesium levels in wild boars in Iitate Village (Tanoi et al. 2016). Wild boars were hunted for pest control and then the organs, tissues, contents of digestive organs, and blood were collected (Figs. 9.3 and 9.4). We investigated seven wild boars in 2012 and two wild boars in 2013. Five were captured in a single cage on November 25, 2012 (identified as 20121125-01 to 20121125-05) and two on November 29, 2012 (20121129-01 and 20121129-02). Two more boars were captured in separate cages on December 6, 2013 (20131206-01 and 20131206-02). Radiocesium in the samples were measured using a $\mathrm{NaI}(\mathrm{Tl})$ scintillation counter $\left(2480\right.$ WIZARD $^{2}$ gamma counter, PerkinElmer, Waltham, MA). Only the radiocesium activities of the blood samples taken in 2012 were measured using a germanium semiconductor detector (GEM-type, ORTEC, SEIKO EG\&G, Tokyo, Japan).

Wild animals hunted as vermin were consumed previously as game meat. In Japan, the radiocesium concentration in food has been controlled according to the sum of ${ }^{134} \mathrm{Cs}$ and ${ }^{134} \mathrm{Cs}$ activities $\left(\mathrm{Bq} \mathrm{kg}^{-1}\right)$. In general, we eat the muscles of wild animals. The average radiocesium concentration in muscle tissues was approximately $15,000 \mathrm{~Bq} \mathrm{~kg}^{-1}$, which was the highest value among the organs tested (Fig. 9.5). In addition to the muscle, most of the organs exceeded the provisional regulation value for meat $\left(500 \mathrm{~Bq} \mathrm{~kg}^{-1}\right.$ ) (Hamada et al. 2012), which was the regulation level of radiocesium until March 31, 2012, although the new standard from April 1, 2012 remains at $100 \mathrm{~Bq} \mathrm{~kg}^{-1}$ (Hamada et al. 2012). The radiocesium concentrations in the ovaries were the lowest among the organs $\left(600 \mathrm{~Bq} \mathrm{~kg}^{-1}\right)$; however, they still exceeded the provisional regulation value (Fig. 9.5). None of the organs were distributed as food.

The ${ }^{137} \mathrm{Cs}$ accumulation patterns were almost the same between 2012 and 2013. The highest ${ }^{137} \mathrm{Cs}$ concentrations were found in the muscles, kidneys, tongue, and heart (Figs. 9.5 and 9.6). The tissues with low ${ }^{137} \mathrm{Cs}$ were similar between 2012 and 2013. The lowest ${ }^{137} \mathrm{Cs}$ concentrations were found in the ovaries, bone, and thyroid glands. The trend is similar to that observed in cattle contaminated by the FDNPP accident in 2011 (Fukuda et al. 2013), whereby the radiocesium concentrations in the muscle, kidney, tongue, and heart were consistently higher than the other organs. In addition to cattle, the radiocesium concentrations were highest in the muscles of pigs fed with brown rice that was contaminated by the FDNPP accident, 

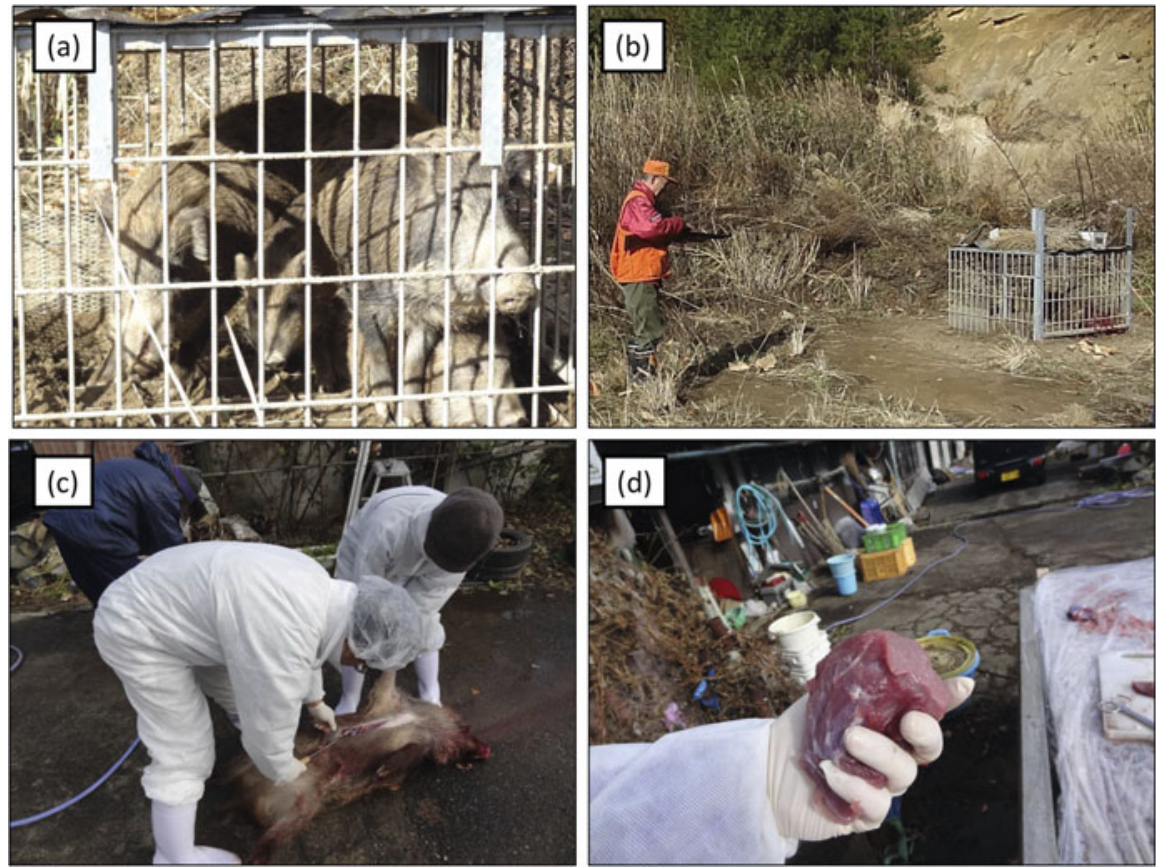

Fig. 9.3 The procedure for collecting wild boars. After capturing the boars in a cage, they were shot and dissected into organs and tissues

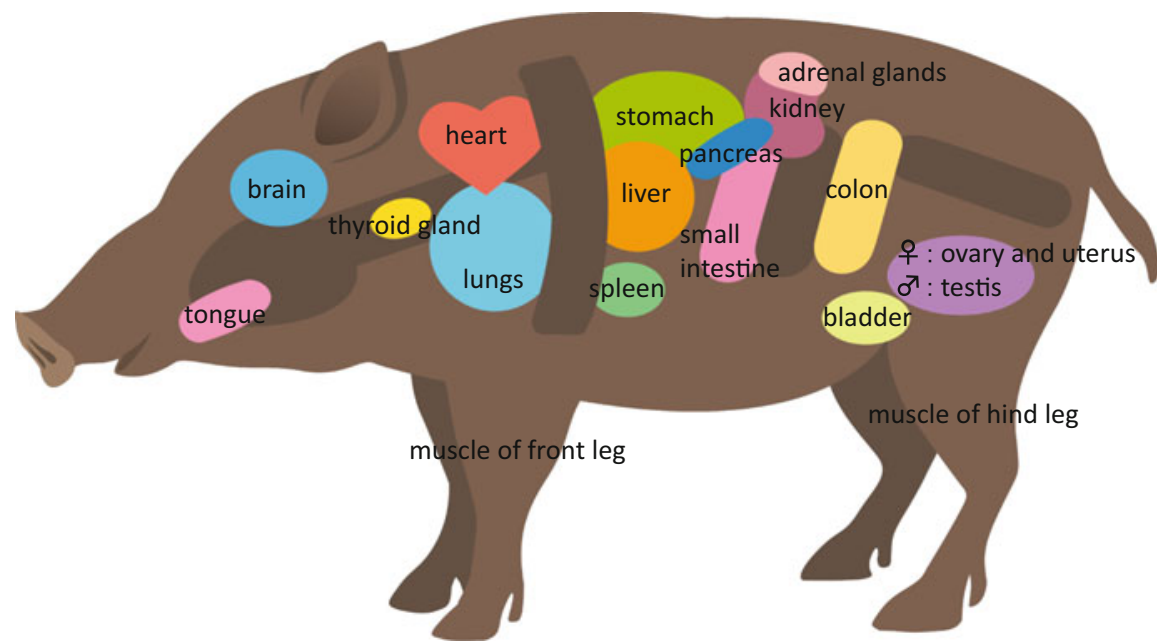

Fig. 9.4 Wild boar anatomy chart 


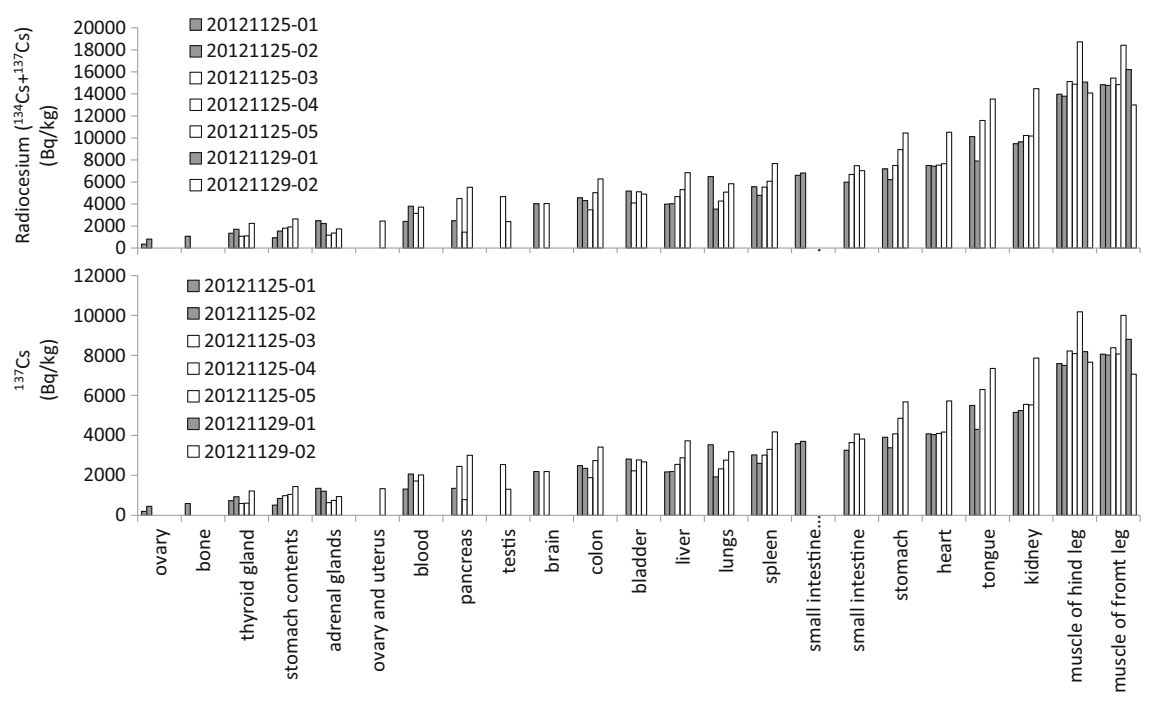

Fig. 9.5 Radiocesium concentrations in the organs and tissues of wild boars in November 2012. The gray bars represent adult boars and white bars represent juvenile boars

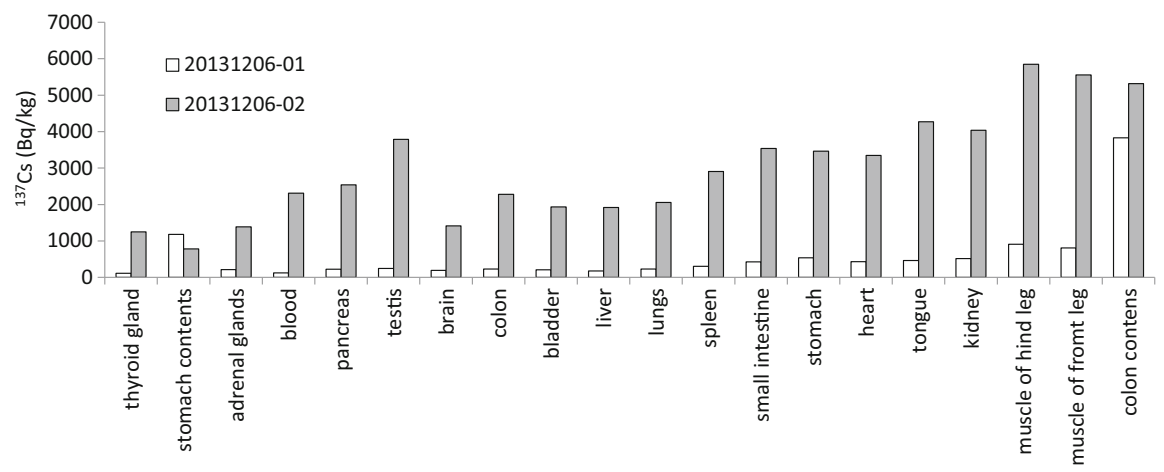

Fig. 9.6 ${ }^{137} \mathrm{Cs}$ concentrations in the organs and tissues of wild boars in winter 2013. The gray bars represent adult boars and white bars represent juvenile boars

followed by the liver and digestive tract, which follow a similar ranking to our data (Ohmori et al. 2014). In addition, when pigs were contaminated by the global fallout around 1950-1960, the ranking of contaminated organs was similar to the present study: higher concentrations in the muscle, kidney, and heart and lower concentrations in the brain, blood, and female reproductive tract (ovary and uterus in our study) (Green et al. 1961).

Wild boars eat a variety of foods such as plants, insects, mushrooms, and small animals; therefore, the radiocesium concentration in the stomach contents reflect the available radiocesium in the forest ecosystem. In the present study, the ${ }^{137} \mathrm{Cs}$ concentrations of boar stomach contents in 2012 and 2013 were almost the same 
Table 9.1 The ratios of blood to muscle in ${ }^{137} \mathrm{Cs}$

\begin{tabular}{l|l|l|l|l}
\hline Animals & Year & Description & $\begin{array}{l}137 \text { Cs ratio of } \\
\text { blood to muscle }\end{array}$ & Reference \\
\hline Wild boar & 2012 & Average of 2 juvenils & 0.22 & $\begin{array}{l}\text { Tanoi et al. } \\
(2016) .\end{array}$ \\
\hline Wild boar & 2012 & Average of 2 adults & 0.23 & $\begin{array}{l}\text { Tanoi } \\
\text { et al. (2016). }\end{array}$ \\
\hline Wild boar & 2013 & Juvenil & 0.14 & $\begin{array}{l}\text { Tanoi } \\
\text { et al. (2016). }\end{array}$ \\
\hline Wild boar & 2013 & Adult & 0.41 & $\begin{array}{l}\text { Tanoi et al. } \\
\text { (2016). }\end{array}$ \\
\hline Pig & $1960 \mathrm{~s}$ & & 0.10 & $\begin{array}{l}\text { Green } \\
\text { et al. (1961) }\end{array}$ \\
\hline Calf & $1960 \mathrm{~s}$ & & 0.01 & $\begin{array}{l}\text { Green } \\
\text { et al. (1961) }\end{array}$ \\
\hline Cattle & 2011 & $\begin{array}{l}\text { Average of } 79 \text { cattles (63 of adults and } \\
13 \text { of calves) }\end{array}$ & 0.04 & $\begin{array}{l}\text { Fukuda } \\
\text { et al. (2013) }\end{array}$ \\
\hline
\end{tabular}

(Figs. 9.5 and 9.6), indicating that the ${ }^{137} \mathrm{Cs}$ situation in the forest did not change between 2012 and 2013. However, the ${ }^{137} \mathrm{Cs}$ concentrations in organs and tissues were different between 2012 and 2013 (Figs. 9.5 and 9.6). It is unclear why stomach contents did not correlate with the organs in terms of ${ }^{137} \mathrm{Cs}$. Furthermore, the reason for different ${ }^{137} \mathrm{Cs}$ concentrations between juveniles and adults in 2013 is unclear. We need to continue monitoring the wild boars to understand the reasons for these results.

Collecting blood is much easier than collecting other organs or tissues. Thus, it is of interest to compare the ${ }^{137} \mathrm{Cs}$ concentrations in blood with those in other organs or tissues. The ${ }^{137} \mathrm{Cs}$ concentration ratios of blood to muscles are summarized in Table 9.1. Unfortunately, the ${ }^{137} \mathrm{Cs}$ ratio of blood to muscle was not consistent, indicating that blood is not a suitable material for monitoring radiocesium concentrations in the muscle of wild boars. We also found species differences, whereby the ratios of ${ }^{137} \mathrm{Cs}$ concentration of blood to muscles in wild boar, 0.24 on average, were much higher than the value of 0.04 reported for cattle (Fukuda et al. 2013), 0.01 for calf (Green et al. 1961), and 0.10 for pig (Green et al. 1961). The reason why these ${ }^{137} \mathrm{Cs}$ concentration ratios differed so markedly among animals remains unclear.

Acknowledgements The authors thank Hidenori Ishii, Tsugio Kanno, Tsuguo Takanashi, Tadashi Yamaguchi, Mitsuro Kanno, and Gohei Hayashi for capturing wild boars; Sadanobu Abe and Koichi Sato for euthanizing wild boars; and Kazuyuki Uchida, Chiyo Doi, Naoto Nihei, Atsushi Hirose, Natsuko I. Kobayashi, Ryohei Sugita, Tatsuya Nobori, Tomoko M. Nakanishi, Muneo Kanno, Ippei Wakabayashi, Miicha Ogawa, and Yoichi Tao for collecting and measuring samples. 
Open Access This chapter is distributed under the terms of the Creative Commons Attribution Noncommercial License, which permits any noncommercial use, distribution, and reproduction in any medium, provided the original author(s) and source are credited.

\section{References}

Fukuda T, Kino Y, Abe Y et al (2013) Distribution of artificial radionuclides in abandoned cattle in the evacuation zone of the Fukushima Daiichi nuclear power plant. PLoS ONE 8:e54312. doi:10.1371/journal.pone.0054312

Green RM, McNeill KG, Robinson GA (1961) The distribution of potassium and caesium-137 in the calf and the pig. Can J Biochem Physiol 39:1021-1026. doi:10.1139/o61-102

Hamada N, Ogino H, Fujimichi Y (2012) Safety regulations of food and water implemented in the first year following the Fukushima nuclear accident. J Radiat Res 53:641-671. doi:10.1093/jrr/ $\operatorname{rrs} 032$

Ohmori H, Sasaki Y, Tajima K, Katsumata M (2014) Radioactive caesium concentrations in pigs fed brown rice contaminated by the Tokyo Electric Power Company Fukushima Daiichi nuclear power plant. Livest Sci 159:156-160. doi:10.1016/j.livsci.2013.10.026

Saito K, Tanihata I, Fujiwara M et al (2015) Detailed deposition density maps constructed by large-scale soil sampling for gamma-ray emitting radioactive nuclides from the Fukushima Dai-ichi Nuclear Power Plant accident. J Environ Radioact 139:308-319. doi:10.1016/j. jenvrad.2014.02.014

Schneider S, Walther C, Bister S et al (2013) Plutonium release from Fukushima Daiichi fosters the need for more detailed investigations. Sci Rep 3:2988. doi:10.1038/srep02988

Steinhauser G, Schauer V, Shozugawa K (2013) Concentration of strontium-90 at selected hot spots in Japan. PLoS ONE 8:e57760. doi:10.1371/journal.pone.0057760

Tanoi K, Uchida K, Doi C et al (2016) Investigation of radiocesium distribution in organs of wild boar grown in Iitate, Fukushima after the Fukushima Daiichi nuclear power plant accident. J Radioanal Chem 307:741-746. doi:10.1007/s10967-015-4233-z

Yasunari TJ, Stohl A, Hayano RS et al (2011) Cesium-137 deposition and contamination of Japanese soils due to the Fukushima nuclear accident. Proc Natl Acad Sci USA 108: 19530-19534. doi:10.1073/pnas.1112058108

Zheng J, Tagami K, Watanabe Y et al (2012) Isotopic evidence of plutonium release into the environment from the Fukushima DNPP accident. Sci Rep 2:304. doi:10.1038/srep00304

Zheng J, Tagami K, Bu W et al $(2014){ }^{135} \mathrm{Cs} /{ }^{137} \mathrm{Cs}$ isotopic ratio as a new tracer of radiocesium released from the Fukushima nuclear accident. Environ Sci Technol 48:5433-5438. doi:10. $1021 /$ es500403h 